\title{
Banfoxanthone, a new prenylated xanthonefrom thestem bark of Garcinia ovalifolia (Guttiferaceae)
}

\author{
Bodrix Solitaire NOUDOU ${ }^{1 *}$, Celine MBAZOA DJAMA ${ }^{2}$, Nathalie Moraine MAMDEM ${ }^{2}$, Justin KOMGUEM ${ }^{2,3}$, \\ Augustin Ephem NKENGFACK ${ }^{2}$, Joseph MBAFOR ${ }^{2}$, Jean WANDJI' \\ ${ }^{1}$ Department of Chemistry, Faculty of Science, University of Bamenda, P.O. Box 39 Bambili, Cameroon. \\ ${ }^{2}$ Department of Organic Chemistry, Faculty of Science, University of Yaounde I, P.O. Box 812 Yaounde, Cameroon.
}

\section{ARTICLE INFO \\ Article history: \\ Received on: 10/03/2015 \\ Revised on: 08/04/2015 \\ Accepted on: 21/04/2015 \\ Available online: $27 / 07 / 2015$}

\section{Key words:}

Garcinia ovalifolia,

Banfoxanthone,

prenylated xanthone,

Guttiferae.

\begin{abstract}
A detailed chemical investigation of the secondary metabolites from the extract of the stem bark of Garcinia ovalifolia led to the isolation of one new prenylated xanthone named banfoxanthone and five known compounds, namely friedeline, canophyllal, ovalifoloneA, 3-methoxycheffouxanthone, endodesmiadol. Prenylated xanthones isolated from Garcinia ovalifolia and others species of genus Garcinia appear to be useful as chemotaxonomic markers in Garcinia.
\end{abstract}

\section{INTRODUCTION}

The genus Garcinia (Guttiferae) is known to produce a variety of biologically active metabolites such as polyisoprenylated benzophenones (Meli Lannang et al., 2010; Gustafson et al., 1992), xanthones (Louh et al., 2008) as well as triterpenoids (Nguyen et al., 2011; Meli Lannang et al., 2008). Some of them exhibited a wide range of biological activities such as cytotoxic, anti-inflammatory, anti-diabetes, anti-fungal, anti-microbial, anti-oxidant and anti HIV activities (Hiroyuki et al., 1996; Nkengfack et al., 2002; Hay et al., 2004; Merza et al., 2004; Lannang et al., 2005). In the continuation of our search for bioactive substances from Garcinia species, we have investigated the hexane and methanol extracts of the stem bark of Garcinia ovalifolia. G. ovalifolia is a tree up to $10-15 \mathrm{~m}$ on high, with yellow sticky latex, generally distributed in fringing forests and river banks in West and central Africa (Gustafson et al., 1992), Asia, New Caledonia and Polynesia (Ampofo and Waterman, 1986).

* Corresponding Author

Bodrix Solitaire NOUDOU, Department of Chemistry, Faculty of Science, University of Bamenda, P.O. Box 39 Bambili, Cameroon. Email: bodrixnoudou[at]yahoo.com
We describe herein the isolation and structure elucidation of minor constituents from G. ovalifolia, which included a new prenylated xanthone namely banfoxanthone (1). Together with three known pentacyclic triterpenes $(\mathbf{2 , 4 , 6 )}$, one known benzophenone (3) and one known xanthone (5).

\section{Experimental}

\section{General experimental procedures}

Optical rotations were measured in methanol solution on a JASCO digital polarimeter (model DIP-3600). The specific rotation is given in $\mathrm{deg} \mathrm{cm} 2 \mathrm{~g} \_$. IR spectra were recorded in $\mathrm{CHCl} 3$ on a JASCO A-302 IR spectrophotometer. The $1 \mathrm{H}, 13 \mathrm{C}$, and 2D-NMR spectra were recorded on a Bruker AMX-500 spectrometer using aceton-d6 as solvent. Homonuclear $1 \mathrm{H}-1 \mathrm{H}$ connectivity were determined by using the COSY 458 experiment. One-bond 1H-13C connectivity were determined by HMQC. Two and three-bond $1 \mathrm{H}-13 \mathrm{C}$ connectivity are determined by $\mathrm{HMBC}$ experiment. Proton and ${ }^{13} \mathrm{C}$ chemical shifts are reported in $\delta$ (ppm). Coupling constants ( $\mathrm{J})$ were measured in Hz. The EIMS were recorded on a double-focusing mass spectrometer (Varian MAT 311A). HREIMS were recorded on a JEOL HX 110 mass spectrometer. 
Column chromatography was carried out with silica gel 60 (70230 and 240-300 mesh sizes, E. Merck) Precoated silica gel TLC plates (E. Merck, F254) were used to check the purity of compounds, and ceric sulfate spray reagent was used for the visualization of compounds on TLC plates.

\section{Plant material}

The stem bark of $G$. ovolifolia was collected from the village Banganfokam, in the west region of Cameroon in February 2010, and identified by the botanist Dr. Tchiengue Barthelemy. A voucher specimen was deposited at the National Herbarium in Yaounde, Cameroon under Ref. $N^{\circ}$ 55523/HNC/CAM/Nkambé.

\section{Extraction and isolation of natural products}

The air-dried and powdered stem bark of $G$. ovolifolia $(1.7 \mathrm{~kg})$ was separately extracted at room temperature for $72 \mathrm{H}$ successively with hexane and methanol. The concentrations of the solutions under reduced pressure yielded $37 \mathrm{~g}$ of hexane extract and $344 \mathrm{~g}$ of methanol extract.

A part of the $\mathrm{MeOH}$ extract $(300 \mathrm{~g})$ was suspended in $2000 \mathrm{ml}$ of aqueous $\mathrm{MeOH}\left(\mathrm{MeOH} / \mathrm{H}_{2} \mathrm{O}, 9: 1\right)$ and extracted with n-hexane $(3 \times 500 \mathrm{ml})$. The aqueous layer was then diluted with 60 $\% \mathrm{MeOH}$ and extracted with $\mathrm{CH}_{2} \mathrm{Cl}_{2}$ (3 x 500ml), then with EtOAc. The n-hexane and $\mathrm{CH}_{2} \mathrm{Cl}_{2}$ extracts were combined on the basis of TLC profile. This combined fraction was purified by column chromatography over silica gel 60 (230-400mesh) and preparative TLC using a gradient system of n-hexane, $\mathrm{CH}_{2} \mathrm{Cl}_{2}$, ethyl acetate and $\mathrm{MeOH}$, yielding friedeline (2) (15.5mg), canophyllal (3) (8.5mg), ovalifolone A (4) (12.0mg), 3methoxycheffouxanthone (5) (12.0mg).

The $n$-hexane extract $(35 \mathrm{~g})$ was chromatographed over a column $(5 \times 80 \mathrm{~cm})$ of silica gel 60 (230-400mesh) eluting with a mixture of $n$-hexane/EtOAc in increasing polarity $(10: 0,1 \mathrm{~L} ; 8: 2$, $1 \mathrm{~L} ; 6: 4,1 \mathrm{~L} ; 4: 6,750 \mathrm{~mL} ; 0: 10500 \mathrm{~mL})$. A total of 130 fractions were collected and subsequently combined into four series of fractions A-D using their TLC profile. Further column chromatography of series A eluted with hex/EtOAc (9.5:0.5 and 9:1) yielded endodesmiadol (6) (11mg). The series B was subjected to silica gel column chromatography and eluted with gradient of hex/EtOAc (9.5:0.5 and 9:1) to obtain endodesmiadol (6) (30mg) and banfoxanthone (1) (10mg).

\section{RESULTS AND DISCUSSION}

\section{Identification of natural products}

As a continuation of our previous phytochemical investigation of the stem bark of Garcinia ovalifolia, the present study report the characterization of a new prenylated xanthone namely banfoxanthone (1).

Banfoxanthone (1) was isolated as yellow needle crystals. The ESI mass spectrum in $\mathrm{MeOH} / \mathrm{H}_{2} \mathrm{O}$ showed the $\mathrm{M}-1$ ion at $\mathrm{m} / \mathrm{z}, 311.0926$ and the $2 \mathrm{M}-1$ ion at $\mathrm{m} / \mathrm{z}, 623.1924$ suggesting the molecular formula to be $\mathrm{C}_{18} \mathrm{H}_{16} \mathrm{O}_{5}$. The $\mathrm{UV}$ spectrum of banfoxanthone (1) showed absorption bands at $\lambda_{\max } 238.00$;
248.92; 264.90 and $313.85 \mathrm{~nm}$ confirming a xanthone derivative (Nkengfack et al., 2002). The IR spectrum exhibited absorption bands at 3430, 2925, 1721 and $1630 \mathrm{~cm}^{-1}$ suggesting the xanthone skeleton with a chelated carbonyl (Federicio et al., 2001).

The ${ }^{1} \mathrm{H}$ and ${ }^{13} \mathrm{CNMR}$ spectra of compound (1) (Table 1) showed a singlet at $\delta_{\mathrm{H}} 12.89$ assigned to an hydroxyl group $(\mathrm{OH}-1)$ which chelated to a carbonyl resonating at $\delta c 184.0$ (C-9). They also showed an aromatic proton singlet at $\delta_{\mathrm{H}} 7.33$ which was assigned to the $\mathrm{C}-4$ position on the basis of the HMBC correlation (Fig. 2) between $\mathrm{H}-4$ and $\delta_{\mathrm{C}} 147.0(\mathrm{C}-4 \mathrm{a})$. An ABC type aromatic proton system was observed at $\delta_{\mathrm{H}} 7.72(1 \mathrm{H}, \mathrm{dd}, \mathrm{H}-8), 7.37(1 \mathrm{H}$, $\mathrm{dd}, \mathrm{H}-6)$ and $7.30(1 \mathrm{H}, \mathrm{t}, \mathrm{H}-7)$ suggesting the presence of three adjacent protons in the same ring. The HMBC spectrum showed correlations between proton at $\delta_{\mathrm{H}} 7.30(\mathrm{H}-7)$ and carbons at $\delta \mathrm{c}$ $116.5(\mathrm{C}-8)$ and $137.9(\mathrm{C}-8 \mathrm{a})$, proton at $\delta_{\mathrm{H}} 7.37(\mathrm{H}-6)$ and carbons at $\delta \mathrm{c} 148.0(\mathrm{C}-5)$ and $142.0(\mathrm{C}-4 \mathrm{~b})$. The ${ }^{1} \mathrm{H}$ and ${ }^{13} \mathrm{CNMR}$ spectra also showed signals at $\delta_{\mathrm{H}} 6.33(1 \mathrm{H}, \mathrm{dd}, \mathrm{H}-2$ '), $5.00(2 \mathrm{H}, \mathrm{d}, \mathrm{H}-3$ ') and $1.5\left(6 \mathrm{H}, \mathrm{s}, \mathrm{CH}_{3}-4^{\prime}\right.$ and $\left.\mathrm{CH}_{3}-5^{\prime}\right)$ suggesting the presence of a prenyl moiety which was connected to the xanthone skeleton using not the usual tail position, but instead an unusual head position (1, 1-dimethylallyl). On the basis of the HMBC spectrum, correlations observed (Fig. 2) between the two methyl protons $\mathrm{CH}_{3}-4$ ' and $\mathrm{CH}_{3}-5,\left(\delta_{\mathrm{H}} 1.5\right)$ and carbon signals at $\delta_{\mathrm{C}} 130.0(\mathrm{C}-3), 123.0(\mathrm{C}-4)$ and $41.0\left(\mathrm{C}-1\right.$ '), and between the singlet signal at $\delta_{\mathrm{H}} 7.33(\mathrm{H}-4)$ and carbon signals at $\delta_{\mathrm{C}} 41.0$ (C-1'), 146.0 (C-2) and 147.0 (C-4a) allowed to link the unusual prenyl $(1,1$-dimethylallyl group) at the C-3 position of the xanthone skeleton. More correlations observed between $\delta_{\mathrm{H}} 12.89(\mathrm{OH}-1)$ and carbon signals at $\delta \mathrm{c} 154.0(\mathrm{C}-1), \delta \mathrm{c}$ 109.0 (C-9a) and 130.0 (C-3), further supported the substitution pattern in ring B. From the above interpretation of spectral data, this compound was established to be a new xanthone derivative, 1 , 2, 5-trihydroxy-3-(1', 1'-dimethylallyl) xanthone, named as banfoxanthone(1).

\section{Previous work}

Previous phytochemical investigations on $G$. ovalifolia have resulted in the isolation of a variety of secondary metabolites which mainly included Guttiferone E (Gustafon et al., 1992), ovalifolone (A), ovalifolone (B), (Lannang et al., 2013), endodesmiadiol and friedeline (Ngouamegne et al., 2008), isoxanthochimol (Louh et al., 2008), 3-methoxycheffouxanthone (Meli et al., 2010), canophyllol (Ngouamegne et al., 2008), canophyllal (Ngouamegne et al., 2008), gallic acid (Sudjaroen et al., 2012), garcinane (Lannang et al., 2013).

\section{Chemotaxonomic significance}

Previous work on this species have permitted to isolate endodesmiadiol, friedeline, canophyllol, canophyllal and the same natural products have been isolated in the species belonging to the Guttiferae family. The same natural product, isoxanthochimol has been isolated also in the species Garciniapolyantha (Louh et al., 2008). Prenylatedxanthones appear to be useful as chemotaxonomic markers in Garcinia. 
<smiles>CO/C(=C\Cc1c(OC)cc(O)c2c(=O)c3c(O)ccc(O)c3oc12)CCC=C(C)C</smiles><smiles>CC1=C(O)C(=O)CC2[C@]1(C)CC[C@@H]1[C@]2(C)CC[C@]2(C)[C@@H]3CC(C)(C)CC[C@@]3(CO)CC[C@]12C</smiles>

4

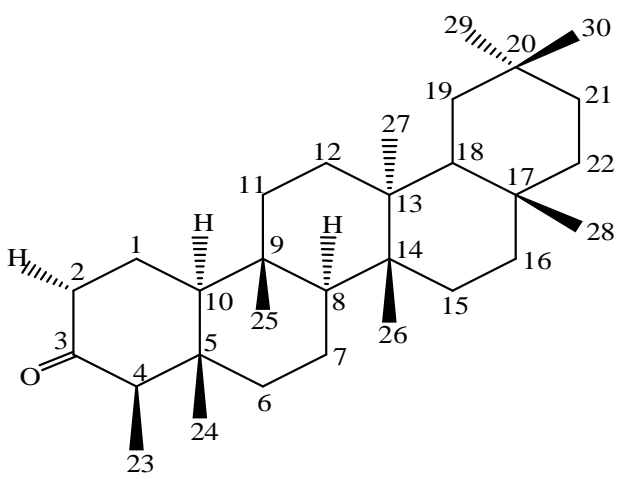

2

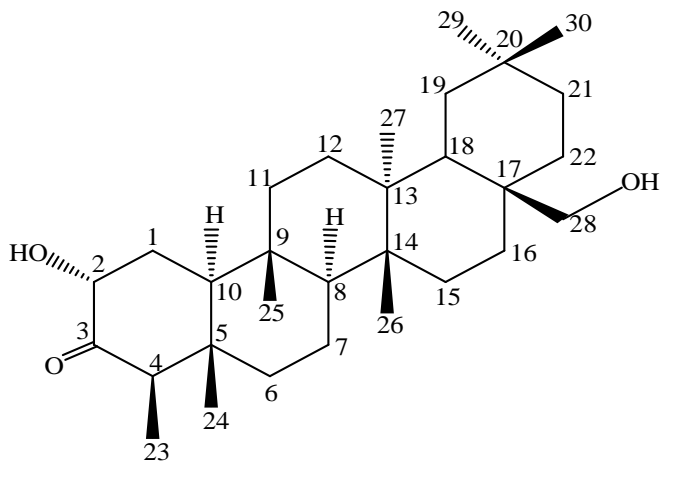

6<smiles>C[C@H]1C(=O)CC[C@H]2[C@@]3(C)CC[C@@H]4[C@](C)(CC[C@@]5(C)CCC(C)(C)C[C@]45C)[C@H]3CC[C@@]21C</smiles><smiles>C=CC(C)(C)c1cc2oc3c(O)cccc3c(=O)c2c(O)c1O</smiles>

Tructures of compounds 2-6

Fig.1: Structure of compound (1).

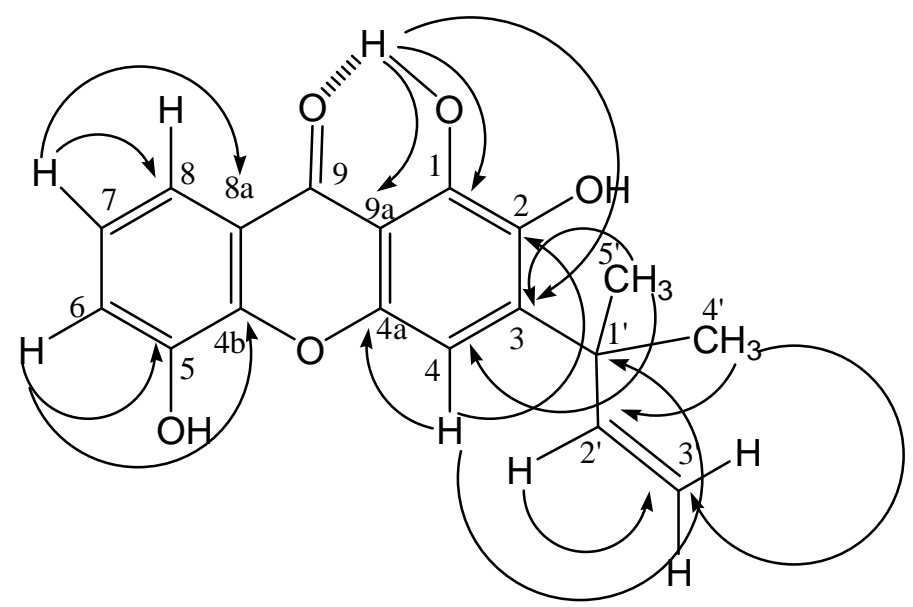

Fig. 2: Key HMBC correlations of compound (1). 
Table 1: The ${ }^{1} \mathrm{H}$ NMR and ${ }^{13} \mathrm{C}$ NMR spectral data and HMBC correlations of compound 1 (aceton- $\mathrm{d}_{6}, 500 \mathrm{MHz}$ for ${ }^{1} \mathrm{H}$ and $125 \mathrm{MHz}$ for ${ }^{13} \mathrm{C}$ ).

\begin{tabular}{|c|c|c|c|}
\hline Position & 1H NMR & 13C NMR & НМВС (H-C) \\
\hline 1 & $12.89(\mathrm{OH}, \mathrm{s})$ & 154.0 & C-1, C-9a, C-3 \\
\hline 2 & $9.00(\mathrm{OH}, \mathrm{s})$ & 146.0 & \\
\hline 3 & - & 130.0 & \\
\hline 4 & $7.33(1 \mathrm{H}, \mathrm{s})$ & 123.0 & $\mathrm{C}-4 \mathrm{a}, \mathrm{C}-1^{\prime}, \mathrm{C}-2$ \\
\hline $4 a$ & - & 147.0 & \\
\hline $4 \mathrm{~b}$ & - & 142.0 & \\
\hline 5 & $9.00(\mathrm{OH}, \mathrm{s})$ & 148.0 & \\
\hline 6 & $7.37(1 \mathrm{H}, \mathrm{dd}, \mathrm{J}=7.9 ; 1.6 \mathrm{~Hz})$ & 125.0 & C-5, C-4a \\
\hline 7 & $7.30(1 \mathrm{H}, \mathrm{t}, \mathrm{J}=7.9 \mathrm{~Hz})$ & 122.0 & $\mathrm{C}-8, \mathrm{C}-8 \mathrm{a}$ \\
\hline 8 & $7.72(1 \mathrm{H}, \mathrm{dd}, \mathrm{J}=7.9 ; 1.6 \mathrm{~Hz})$ & 116.0 & \\
\hline $8 a$ & - & 137.9 & \\
\hline 9 & - & 184.0 & \\
\hline $9 \mathrm{a}$ & - & 109.0 & \\
\hline 1 & - & 41.0 & \\
\hline 2 ' & $6.33(1 \mathrm{H}, \mathrm{dd})$ & 148.0 & C-3' \\
\hline $3^{\prime}$ & $5.00(2 \mathrm{H}, \mathrm{d})$ & 111.0 & \\
\hline 4 ' & $1.50(3 \mathrm{H}, \mathrm{s})$ & 26.5 & $\mathrm{C}-1^{\prime}, \mathrm{C}-3, \mathrm{C}-4, \mathrm{C}-2^{\prime}, \mathrm{C}-3^{\prime}$ \\
\hline 5, & $1.50(3 \mathrm{H}, \mathrm{s})$ & 26.5 & $\mathrm{C}-1$ ', C-3, C-4, C-2', C-3' \\
\hline
\end{tabular}

\section{CONCLUSION}

From the stem bark of Garciniaovalifolia, a new prenylated xanthone namely banfoxanthone (1) together with three known pentacyclic triterpenes (friedelan(2), ovalifoloneA(4), endodesmiadol(6)), one known benzophenone(canophyllal(3)) and one known xanthone(3-methoxycheffouxanthone(5)) have been isolated. According to the previous works done on some species of genus Garcinia and others species belonging to the guttiferae family, we finally conclude that prenylated xanthones appear to be useful as chemotaxonomic markers in Garcinia.

\section{ACKNOWLEDGEMENTS}

One of us Justin Komguem, is thankful to the DAAD for financial support for research. We thank Dr. Tchiengue Barthelemy (botanist) for the collection and identification of the plant material and also thank, $H$. Laatsch at the Institutfür Organische Chemie Der Georg-August-Universität Tammannstra ße 2 D-37077 Göttigen, Germany for the supporting recording of NMR spectra.

\section{Author(s)' Statement(s) \\ Competing Interests}

The author(s) declare(s) no conflict of interest and competing interests in this work.

\section{Informed Consent, Ethical Approvals}

Plant material used in this work is commercially available and does not need any informed consent from the local populations.

\section{REFERENCES}

Ampofo A.S, Waterman G.P. Xanthones from three Garcinia species. Phytochemistry, 1986; 25: 2351-2355.

Bennett G.J, Lee H.H. Xanthones from Guttifereae. Phytochemistry, 1989; 28: 967-998.

Gustafson K.R, Blunt J.W, Munro M.H.G, Fuller R.W, McKee T.C, Cardellina II J.H, McMahon J.B, Cragg G.M, and Boyd M.R. The guttiferones, HIV inhibitory agents from Symphonia globulifera, Garcinia livingstonei, Garcinia ovalifolia and Clusia rosea. Tetrahedron, 1992; 48:10093-10102.

Hay A.E, Aumond M.D, Mallet S, Dumonted V, Litaudon M, Rondeau D, Richomme P. antioxidant xanthones from Garcinia vieillardii. J. Nat. Prod., 2004; 67: 707-709.

Hiroyuki M, Emi T, Mitsuaki K, Yoshiyasu F. Phytochemistry, 1996; 41: 629-633.

Lannang M.A, Komguem J, Ngninzeko F.N, Tangmouo J.G, Lontsi D, Ajaz A, Choudhary M.I, Ranjit R, Devkota K.P, Sondengam B.L. Bangangxanthone A et B, two xanthones from the stem bark of garcinia polyantha oliv. Phytochemistry, 2005; 66: 2351-2355.

Lannang M.A, Noudou S.B, Sewald N. Ovalifolone A and B: New friedelane derivatives from Garcinia ovalifolia. Phytochemistry Letters, 2013; 6: 157-161.

Louh N. G, Meli Lannang A, Mbazoa D. C, Tangmouo J. G, Komguem J, Castillo P, Mofo F.N, Naz Q, Lontsi D, Iqbal M. C, Sondengam B.L. Polyanxanthone A, B and C, three xanthones from the wood trunk of Garcinia polyantha Oliv. Phytochemistry, 2008;69:10131017.

Meli Lannang A, Louh G. N, Biloa B. M, Komguem J, Mbazoa D. C, Sondengam B.L,Naesens L, Pannecoupe C, Clerq E. D, Ashry E.S.H.E. Cytotoxicity of natural compounds isolated from the seed of Garcinia afzelii ENGL. (Guttiferae). Planta Med., 2010; 76 : 708-712.

Merza J, Aumond M.C, Rondeau D, Dumontet V, Le Ray A.M, Séraphin D, Richomme P. Phytochemistry, 2004 ; 65 : 2915-2920.

Ngouamegne E. T, Fongang R. S, Ngouela S, Boyom F. F, Rohmer M, Tsamo E, Gut J, Rosenthal P. Endodesmiadiol, a friedelane triterpenoid, and other antiplasmodial compounds from Endodesmia calophylloides. J. Chem. Pharm. Bull., 2008 ; 56: 374-377

Nkengfack E.A, Mkounga P, Fomum T.Z, Meyer M, Bodo B. globulixanthones A et B, two new cytotoxic xanthones with isoprenoid groups from the root bark of Symphonia globulifera. J. Nat. Prod., 2002; 65: 734-736.

Peres V, Nagem T.J, Oliveira F.F. Tetraoxygenated Naturally Occurring Xanthones Phytochemistr, 2000; 55: 683-710.

Sudjaroen Y, Hull W. E, Erben G, Würtele G, Changbumrung S, Ulrich C. M, Owen R. W. Phytochemistry, 2012; 77: 226-237.

\section{How to cite this article:}

Bodrix Solitaire Noudou, Celine Mbazoa Djama, Nathalie Moraine Mamdem, Justin Komguem, Augustin Ephem Nkengfack, Joseph Mbafor, Jean Wandji. Banfoxanthone, a new prenylated xanthone from the stem bark of Garcinia ovalifolia (Guttiferaceae). J App Pharm Sci, 2015; 5 (07): 136-139. 